\title{
Leprosy and Eye Injuries
}

\author{
Chowdhury $S^{1 *}$, Sneha ${ }^{2}$, Priyanka ${ }^{2}$ and Harsha ${ }^{2}$ \\ ${ }^{1}$ Chief Ophthalmologist, SAIL, Bokaro general hospital, India \\ 2DNB Residents, Bokaro general hospital, India
}

*Corresponding author: Sanjoy Chowdhury, MS.DO.DNB. 4C/3020, Bokaro steel city, Jharkhand.-827004, India, Tel: 8986872947; Email: drsanjoy@hotmail.com

\section{Research Article \\ Volume 4 Issue 1}

Received Date: December 31, 2018

Published Date: January 23, 2019

DOI: $10.23880 /$ cdoaj- 16000169

\section{Abstract}

Aim: To study the prevalence of eye injuries in leprosy and normal patients.

Methods: This is an observational study conducted in 200 members, of which 100 leprosy patients were taken as cohort and 100 healthy normal individuals were taken as controls in a village Kumrudih over the period from June 2017 - June 2018. After taking consent detailed medical history was taken from each individual and clinical eye examination was done and findings were recorded.

Results: Out of 100 leprosy patients 8 had trauma to eye, 20 had corneal foreign body, 20 had corneal ulcer had undergone delayed treatment as they were unaware of injuries mostly so visual outcome was worse. Out of 100 healthy controls 2 had history of trauma to eye, 6 had corneal foreign body, 4 had corneal ulcer had undergone early treatment and visual outcome was good.

Conclusion: Leprosy patients are more prone to eye injuries than healthy normal individuals. So early diagnosis and early intervention prevents the poor visual outcome in leprosy patients.

\section{Introduction}

According to official reports received from 138 countries from all WHO regions, the global registered prevalence of leprosy at the end of 2015 was 176176 cases ( 0.2 cases per 10000 people). The village where this study was conducted falls under the area with annual incidence of more than 1000 cases [1].

Leprosy is a chronic infectious disease, the incidence of which varies widely in different parts of the world. Leprosy is caused by Mycobacterium leprae (Hansens bacillus). It involves superficial ocular tissues and can cause blindness. The bacillus affects the zygomatic branch of nervus facialis and corneal nerves innervated by the ophthalmic branch of the trigeminal nerve [2].
Incidence of ocular injuries like trauma,corneal foreign body in the eye, corneal ulcer etc. are associated with worse visual outcome and often leads to blindness in leprosy patients as compared to healthy individuals as they were unaware of causes. These leads to delayed presentation by patient and hence higher ocular morbidity.

Blindness for leprosy patients is disastrous as they depend on their vision to protect their limbs from the injuries and burns that are due to the numbness and loss of sensation caused by the disease. This visual disability is to a large extent preventable, provided that the ocular involvement is diagnosed at an early stage and appropriate measures are undertaken in time [3]. 
Although leprosy has been known to be associated with reduced corneal sensitivity, rate of blinking and lagophthalmous which ultimately leads to dry eye. Inaccessibility to health care along with severe dryness leads to morbid lesions of the eye. In this study we have compared the prevalence and type of eye injuries in leprosy patients to that of normal healthy individuals and find out who are more prone to ocular injuries.

\section{Methodology}

It is an observational study, conducted at village Kurmudih, jharkhand for period of 2017 june to 2018 june. A total of 200 individuals were included with mean age $>40 \mathrm{yr}$ of M:F ratio 15:2. Of which 100 diagnosed cases of leprosy were included in this study as cohort group and 100 normal healthy individuals as controls who had no systemic diseases were included in this study.All the diagnosed or newly diagnosed cases were enrolled for multi- drug chemotherapy. After proper consent was taken, Individuals data on age, sex, and history were taken regarding eye injuries. A torch light Eye examination included the assessment of visual acuity, eye lid position-lagophthalmos corneal opacities, corneal ulcers, stability of the tear film was tested by schirmer's test and TBUT , corneal sensation was tested.

TBUT test done by taking the time for occurrence of the first dry spot on the cornea after the last blink was noted.
A TBUT of $<10$ sec was considered diagnostic of dry eyes with deficiency of mucin. Corneal sensation was tested by asking the patient to look straight ahead and touch the cornea by piece of cotton, if the patient feels the sensation and blinks then its positive.

\section{Results}

A total of 200 eyes of leprosy patients as cohort and 200 eyes of healthy ones as controls were included in this group.

\section{In leprosy patients}

Out of 100, 8 had trauma to the eye and lost the vision, 20 patients had corneal foreign body most of which were asymptomatic and hence diagnosed on routine examination. 20 had asymptomatic corneal ulcer. Due to delayed intervention, visual outcome was worse as compared to the controls.

An abnormal TBUT of $0-15$ sec was seen in $47.2 \%$ eyes, while $52.8 \%$ of the eyes had a normal TBUT $>15 \mathrm{sec}$.

Lagophthalmous was seen in 20 eyes. Among patients with lagophthalmous, 70\%patients had abnormal TBUT, while $25 \%$ showed normal TBUT. Corneal sensations were diminished in $54 \%$ of the eyes.

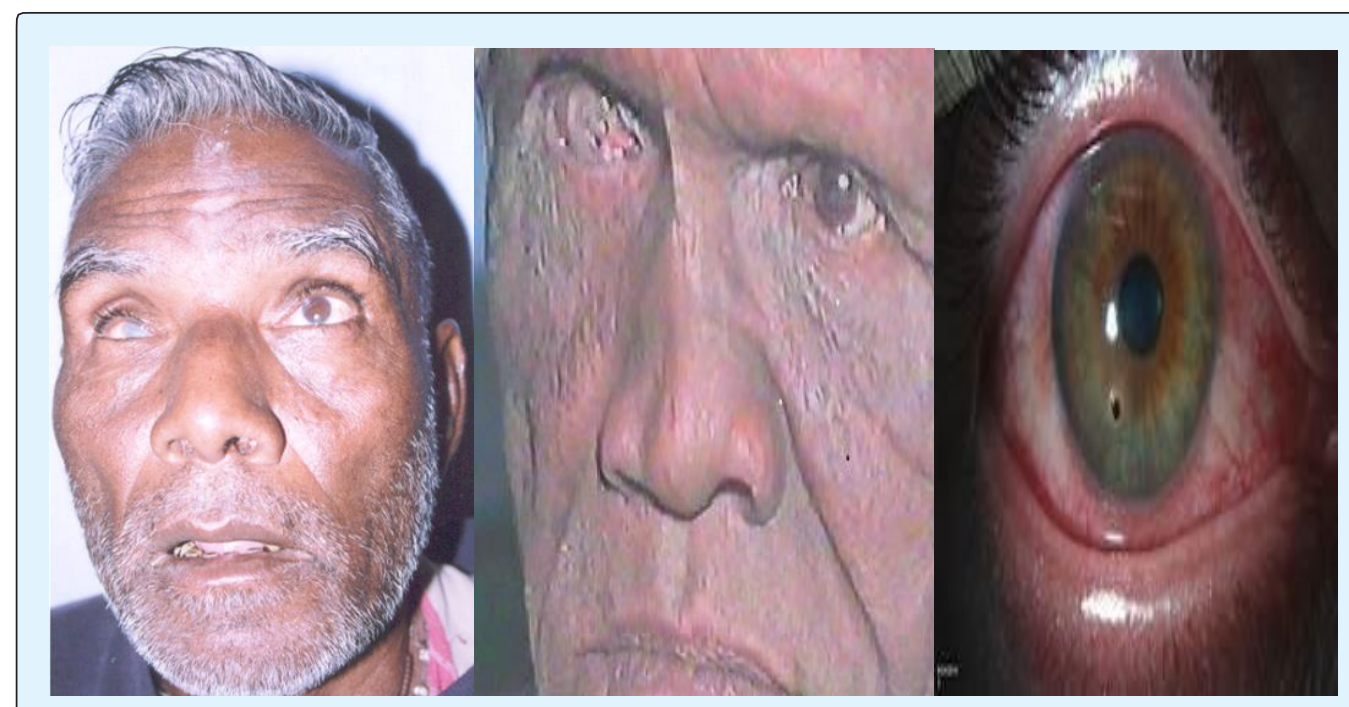

Figure 1: A: Corneal opacity, B: Trauma to eye, C: Corneal foreign body. 


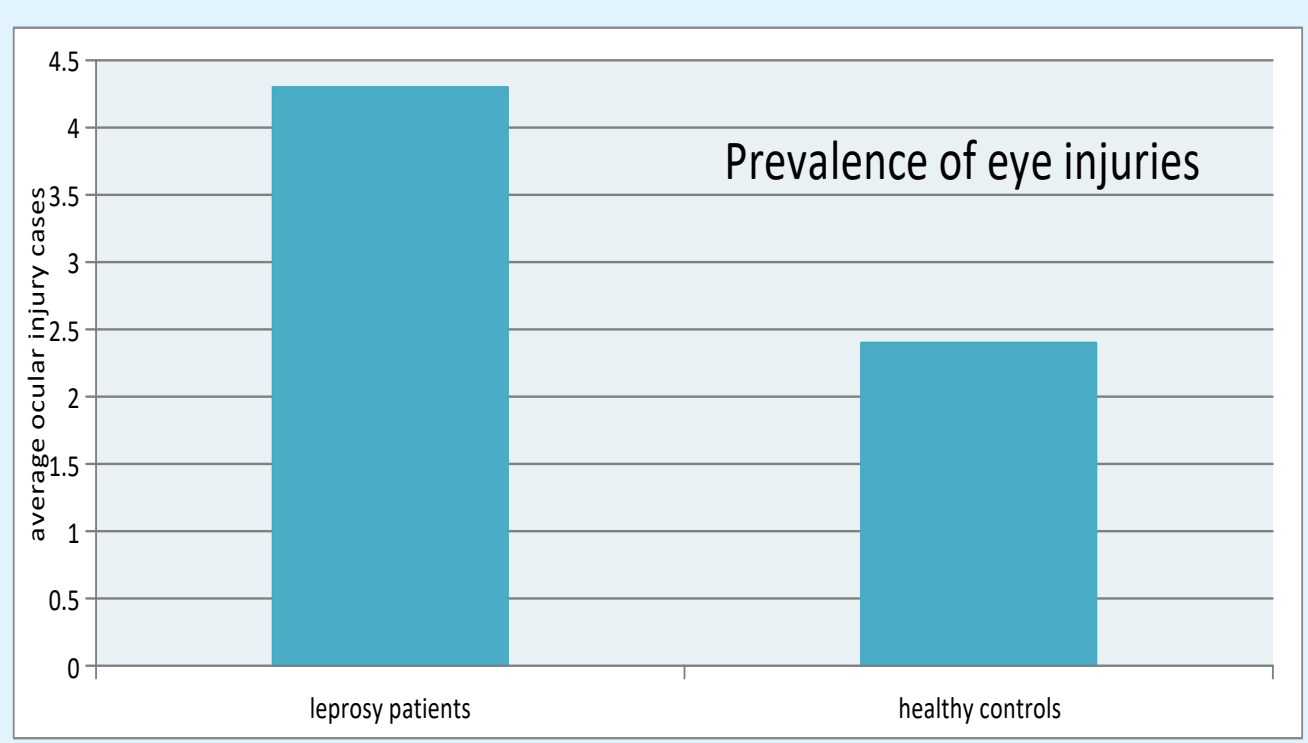

Figure 2: Graph showing prevalence of ocular injury cases compared to healthy individuals.

\section{In controls}

Out of 100, 2 had trauma to the eye, of which one lost vision and one had 6/36 vision, 6 had corneal foreign body but removed on complaining, 4 had corneal ulcer had undergone treatment and recovered early. So visual outcome was good in controls.

An abnormal TBUT of $0-15 \mathrm{sec}$ was seen in 16 eyes, while 184 eyes had normal TBUT>15sec.Lagophthalmous was seen in only 4 eyes, of these one eye associated with abnormal TBUT. No patient found with corneal sensation loss.

\begin{tabular}{|c|c|c|c|c|}
\hline & $\begin{array}{c}\text { Cornea } \\
\text { Foreign } \\
\text { body }\end{array}$ & $\begin{array}{c}\text { Corneal } \\
\text { ulcer }\end{array}$ & $\begin{array}{c}\text { Trauma } \\
\text { to eye }\end{array}$ & $\begin{array}{c}\text { Visual } \\
\text { outcome }\end{array}$ \\
\hline $\begin{array}{c}\text { Leprosy } \\
\text { pts 100 }\end{array}$ & 20 & 20 & 8 & Poor \\
\hline $\begin{array}{c}\text { Healthy } \\
\text { controls } \\
100\end{array}$ & 6 & 4 & 2 & Good \\
\hline
\end{tabular}

Table 1: Type of ocular injury with occurrence in leprosy and healthy controls.

\begin{tabular}{|c|c|c|c|}
\hline & $\begin{array}{c}\text { Leprosy } \\
\text { patients }\end{array}$ & $\begin{array}{c}\text { Healthy } \\
\text { individuals }\end{array}$ & TOTAL \\
\hline $\begin{array}{c}\text { Exposure to } \\
\text { corneal foreign } \\
\text { body }\end{array}$ & 20 & 06 & 26 \\
\hline
\end{tabular}

\begin{tabular}{|c|c|c|c|}
\hline $\begin{array}{c}\text { Non exposure to } \\
\text { corneal foreign } \\
\text { body }\end{array}$ & 80 & 94 & 174 \\
\hline TOTAL & 100 & 100 & 200 \\
\hline
\end{tabular}

Table 2: Comparison between prevalence of corneal foreign body in two groups.

From above table Odds ratio calculated

Odd ratio $=20 * 94 / 80 * 6=3.9$

It shows odds ratio $>1$, so leprosy patients are more prone to eye injuries (corneal foreign body exposure).

\begin{tabular}{|c|c|c|c|}
\hline & $\begin{array}{c}\text { Leprosy } \\
\text { patients }\end{array}$ & $\begin{array}{c}\text { Healthy } \\
\text { controls }\end{array}$ & Total \\
\hline $\begin{array}{c}\text { Corneal } \\
\text { ulcer }\end{array}$ & 20 & 04 & 24 \\
\hline $\begin{array}{c}\text { No corneal } \\
\text { ulcer }\end{array}$ & 80 & 96 & 176 \\
\hline Total & 100 & 100 & 200 \\
\hline
\end{tabular}

Table 3: Comparison between prevalence of corneal ulcer in both groups.

From above table Odds ratio calculated

Odds ratio $=20 * 96 / 80 * 4=6$

It shows odds ratio $>1$, so leprosy patients are more prone to eye injuries(corneal ulcers) 


\section{Clinical Dermatology Open Access Journal}

\begin{tabular}{|c|c|c|c|}
\hline & $\begin{array}{c}\text { Leprosy } \\
\text { patients }\end{array}$ & $\begin{array}{c}\text { Healthy } \\
\text { individuals }\end{array}$ & Total \\
\hline $\begin{array}{c}\text { Eye } \\
\text { trauma }\end{array}$ & 08 & 02 & 10 \\
\hline $\begin{array}{c}\text { No Eye } \\
\text { trauma }\end{array}$ & 92 & 98 & 190 \\
\hline TOTAL & 100 & 100 & 200 \\
\hline
\end{tabular}

Table 4: Comparison between prevalence of eye trauma in both groups.

From above table Odds ratio calculated:-

Odds ratio $=8 * 98 / 92 * 2=4.2$

Odds ratio shows $>1$, so leprosy patients are more prone to eye injuries (Eye trauma).

\section{Discussion}

In leprosy the organ most often involved after the skin, nasal mucosa and peripheral nerves is the eye. The eye is liable to infiltration as soon as the disease agent disseminates through the blood stream. The leprosy bacilli may be present in any part of the eye, but the main lesion is almost always in the structures of in anterior segment [4]. Dry eye occurrence in leprosy patients is due to decreased reflex secretion from the lacrimal gland. An abnormal TBUT was frequently observed in this study results which could be explained by poor lubrication and wetting of the corneal epithelium. A continuous tear film across the cornea and conjunctival surface, forms with difficulty due to lack of good blinking of lids and a deficiency of mucin layer in leprosy. Regardless of the origin all dry eyes leads to desiccation and necrosis of conjuvctival epithelium with the cornea ultimately responding with vessel in-growth and scarring, thus leads to eye morbidity. Corneal sensitivity is reduced in leprosy patients .As there is lagophthalmous and decreased reflex blinking seen in leprosy patients compared to controls, the patients are more prone to exposure to foreign bodies and often associated with late presentation, due to corneal hyposthesia in these patients. Further corneal ulceration leads to corneal opacity which ultimately leads to blindness in leprosy patients.
Corneal opacity is the commonest cause of blindness, which is logical as lagophthalmous and corneal ulceration are more common. The study done in Nigeria 28\% leprosy patients were blind due to corneal opacity, it confirms that cornea is a target organ either indirectly or directly through the spread bacilli by an exogenous, haematogenous, or neurogenous route [5].

From this study it shows that leprosy patients are more prone to eye injuries than normal healthy individuals. An eye injury causes blindness in leprosy patients due to reduced blinking, corneal hyposthesia and lagophthalmous.

So, early diagnosis, regular eye check -ups, selfexamination, self-protection, and early intervention can reduce the eye morbidity in leprosy patients. In remote areas where health facility is scarce awareness regarding disease entity and prevention are the best tools in improving the overall quality of life of leprosy patients.

\section{References}

1. World Health Organisation (2015) Epidemiology.

2. Ridley MJ (1986) Lepraninmicrobiyoljisi. In: Saylan T, Sultas M (Eds.), 11 UlusalLepraSemineri, Istanbul: Yaylacik Matbassi, pp: 65-71.

3. Thompson KJ, Allardice GM, Babu GR, Roberts H, Kerketta W, et al. (2006) Patterns of ocular morbidity and blindness in leprosy - a three centre study in Eastern India. Lepr Rev 77: 130-140.

4. Brand MB (1987) Care of the eye in Hansen disease. $2^{\text {nd }}($ Edn.), Carville, LA; Star, pp: 3-14.

5. Vedy J (1988) Precise "Ophthalmologice Tropicale. $2^{\text {nd }}$ (Edn.), Marseille: Diffusion de Librairie, pp: 251.

6. Mpyet C, Solomon AW (2005) Prevelence and causes of blindness and low vision in leprosy villages of north eastern Nigeria. Br J Ophthamol 89: 417-419. 